\title{
Genesis and prerequisites for creating stock markets for small and medium-sized enterprises
}

\author{
Magdalena Mosionek-Schweda*
}

\section{Introduction}

According to the statistics of the European Statistical Office, in 2014 in the 28 European Union member states, there were about 22 million businesses (operating in the non-financial sector) belonging to the category of small and medium-sized enterprises (SMEs), which accounted for $99.8 \%$ of all enterprises. These entities employed 90 million workers (67\% of total employees), and their share in the EU's GDP was at that time around 28\% (European Commission 2015, p. 13-16). Despite the important role of SMEs in the economy of each country, their functioning and development are limited by the insufficient availability of funding.

The problem of the financial sector discriminating against small and mediumsized enterprises was recognized in the 1930s. In 1931 in the UK, the Macmillan Commission published a report which drew attention to the existence of a gap between the insufficient supply and demand for capital, experienced mainly by entities from the SME sector ${ }^{1}$. According to the report, all companies had equal access to short-term capital, but the financial market did not meet the needs for medium and long term capital ranging from five thousand to two hundred thousand pounds (Jóźwiak-Mijal 2005, p. 49). Funds of more than two hundred thousand pounds were available through the public issue of shares or bonds, unreachable for SMEs. In turn, banks were reluctant to become involved in financing SMEs due to excessive risk associated with such investments.

\footnotetext{
* Magdalena Mosionek-Schweda, Uniwersytet Gdański, Wydział Ekonomiczny, Instytut Handlu Zagranicznego, Zakład Międzynarodowych Rynków Finansowych.

1 Known as „Report of the Macmillan Committee about deficiencies in the supply of capital, especially equity capital, to smaller British business" (Arcot, Black, Owen 2007, p. 11-12).
} 
Among the proposed solutions to the problem of financing SMEs there was a proposal to use the capital market, including the stock exchange. The first steps in this direction, however, were not taken until the 1970s through the creation of special trading platforms designed for SMEs determined to raise funds through the issue of shares or bonds. These markets are characterized by less restrictive regulations concerning admission to trading, and then listing, taking into account the specificity of SMEs. These platforms are the subject of this study. The aim of this article is to identify and evaluate the reasons for creating markets for SMEs, including the role the European Commission has played in this matter. The performed analysis includes only markets created by stock exchanges but omits other platforms, for example those organized by investment firms. The work is based on literature studies, legal acts analysis, as well as the data obtained from the websites of stock exchanges and the Federation of European Securities Exchanges (FESE).

\section{Genesis and prerequisites for the creation of junior markets}

The history of securities markets dedicated to small and medium-sized enterprises begins in the United States with the NASDAQ (National Association of Securities Dealers Automated Quotations) launched in 1971. It is, however, an OTC market, organized and supervised by the National Association of Securities Dealers. It is also the world's first fully electronic securities trading platform. Thanks to the flexible and less restrictive regulations, compared to the New York Stock Exchange (NYSE), the NASDAQ is available to companies unable to meet the conditions of entry to the main market. The list of well-known companies listed on the NASDAQ includes Microsoft, Amazon, Google, Dell and eBay. Instruments of more than 2,800 companies operating in the area of new technologies, telecommunications and accounting services are currently traded on the NASDAQ ${ }^{2}$.

In Europe, the first markets for trading instruments issued by SMEs appeared in the late 1970s: in 1977, the French stock market created Compartiment Spécial, a year later Mercato Ristretto was established in Italy. These markets were called "junior markets" or "second-tier markets". Over the next four decades, other stock exchanges broadened the offer by opening trading platforms designed for SMEs; there were also a lot of ideas to create such markets that had not been implemented (see: table 1).

2 As of 31 march 2016, Nasdaq listed instruments issued by 2852 companies. World Federation of Exchanges (2016), Monthly Report 03/2016, http://www.world-exchanges.org/home/ index.php/statistics/monthly-reports (access: 30.04.2016). 
Table 1. European stock exchange share markets for small and medium-sized enterprises

\begin{tabular}{|c|c|c|}
\hline Year* & Stock Exchange & Name of market \\
\hline 1977 (c) & Bourse de Paris (France) & Compartiment Spécial \\
\hline 1978 (c) & Borsa Italiana (Italy) & Mercato Ristretto \\
\hline 1980 (c) & London Stock Exchange (Great Britain) & Unlisted Securities Market \\
\hline $1982(c)$ & Københavns Fondsbørs (Denmark) & Aktiemarked III \\
\hline 1982 (c) & Amsterdamse beurs (Holland) & Officiele Parallel Markt \\
\hline 1982 (c) & Bolsa de Barcelona (Spain) & Segundo Mercado \\
\hline $1982(c)$ & Stockholmsbörsen (Sweden) & Swedish OTC Market \\
\hline 1983 (c) & Bourse de Paris (France) & Second Marché \\
\hline 1984 (c) & Oslo Børs (Norway) & Børs II \\
\hline 1984 (c) & Bourse de Bruxelles (Belgium) & Second Marché \\
\hline $1986(r)$ & Bolsa de Bilbao (Spain) & Segundo Mercado \\
\hline $1986(r)$ & Bolsa de Madrid (Spain) & Segundo Mercado \\
\hline $1986(p)$ & Bolsa de Valencia (Spain) & Segundo Mercado \\
\hline 1987 (c) & Deutsche Börse (Germany) & Geregelter Markt \\
\hline 1987 (c) & London Stock Exchange (Great Britain) & Third Market \\
\hline 1992 (c) & Amsterdamse beurs (Holland) & Dutch Participation Exchange \\
\hline $1992(p)$ & Bolsa de Valores de Turín (Italy) & Mercato Locale Del Nord Ovest \\
\hline $1993(p)$ & London Stock Exchange (Great Britain) & The Enterprise Market \\
\hline $1993(p)$ & London Stock Exchange (Great Britain) & The National Market \\
\hline 1993 (c) & Bourse de Paris (France) & Second Marché II \\
\hline $1994(p)$ & Bourse de Paris (France) & MESEC \\
\hline 1995 & London Stock Exchange (Great Britain) & Alternative Investment Market \\
\hline $1996(r)$ & Bourse de Paris (France) & Nouveau Marché \\
\hline 1997 (c) & Bourse de Bruxelles (Belgium) & Euro.NM Belgium \\
\hline 1997 (c) & Amsterdamse beurs (Holland) & Euro.NM Amsterdam \\
\hline $1997(r)$ & Deutsche Börse (Germany) & Neuer Markt \\
\hline 1998 & Stockholmsbörsen (Sweden) & Nya Marknaden \\
\hline 1999 & Schweizer Börse (Switzerland) & SWX New Market \\
\hline 1999 & Helsingin Pörssi (Finland) & NM-List \\
\hline 1999 & London Stock Exchange (Great Britain) & Techmark \\
\hline 1999 (c) & Borsa Italiana (Italy) & Nuovo Mercato \\
\hline 1999 (c) & Deutsche Börse (Germany) & SMAX \\
\hline 1999 (c) & Wiener Börse (Austria) & Austrian Growth Market \\
\hline $2000(r)$ & Bolsa de Madrid (Spain) & Nuevo Mercado \\
\hline $2000(r)$ & Københavns Fondsbørs (Denmark) & KVX Growth Market \\
\hline 2000 (c) & Stocmhalartán na hÉireann (Ireland) & ITEQ \\
\hline $2000(p)$ & $\begin{array}{l}\text { London Stock Exchange (Great Britain), Deutsche } \\
\text { Börse (Germany) }\end{array}$ & iX-Nasdaq Merger \\
\hline 2001 (c) & American Stock Exchange & Nasdaq Europe \\
\hline 2002 & Euronext & NextEconomy \\
\hline 2003 & Deutsche Börse (Germany) & Prime Standard \\
\hline 2005 & Euronext & Alternext \\
\hline
\end{tabular}


Table 1. (cd.)

\begin{tabular}{|l|l|l|}
\hline \multicolumn{1}{|c|}{ Year* } & \multicolumn{1}{|c|}{ Stock Exchange } & \multicolumn{1}{c|}{ Name of market } \\
\hline 2005 & Deutsche Börse (Germany) & Entry Standard \\
\hline 2005 & Stocmhalartán na hÉireann (Ireland) & IEX \\
\hline 2005 & Nasdaq OMX & First North \\
\hline 2007 & Warsaw Stock Exchange (Poland) & NewConnect \\
\hline 2007 & Oslo Børs (Norway) & Oslo Axess \\
\hline 2008 & Bolsas y Mercados Españoles (Spain) & MAB Mercado Alternativo Bursátil \\
\hline 2012 & Borsa Italiana (Italy) & AIM Italia \\
\hline
\end{tabular}

* Year of commencement of operation, and in the case of markets planned to be set up, which ultimately did not start, indicated the date of commencement of work on the concept.

c - a closed market; $\mathrm{p}$ - a market planned to start; $\mathrm{r}$ - a reformed market

Source: own studies based on Posner 2009 and the websites of the presented stock exchanges.

Analyzing the reasons of creating trading markets for SMEs, the adopted formal and legal solutions, and the organizational structures, two stages in the history of their operation may be distinguished: 1977-1994 and the period since 1995.

The first junior stock exchange markets created in the 1970s and 1980s played only a secondary role in relation to the main market and were regarded a funding source for this platform. Referred to as "feeder market", their main role was to prepare the listed companies to switch to the main trading floor, although officially it was stressed that their task was to support SMEs in accessing financing through the issuance of shares. Creating junior markets was largely to be a solution for problems the stock exchanges then faced, above all, a huge decline in the number of listed companies and IPOs. In 1962, the Paris Stock Exchange listed 1,566 companies; twenty years later the number dropped to 707. The London Stock Exchange (LSE) recorded a decrease from 3,816 issuers in 1955 to 2,052 in 1979, while in Germany of 686 listed companies in 1956, only 452 were left in 1982. The deterioration of the situation on the trading floors was further compounded by the decreasing number of IPOs. In France, the annual average of about 60 IPOs in the 1960s fell to only five in the 1980s. In Germany, in 19771982 there were only nine IPOs. The stock market in Austria in 1962-1982 recorded none (Rasch 1994, p. 2). Creating special trading platforms characterized by lower requirements for IPOs and listed companies next to the main markets, the stock exchanges planned to attract new issuers.

Initially, the markets for SMEs developed dynamically. The Unlisted Securities Market (USM) in London listed 23 companies in the first year, and 448 entities with a total capitalization of $£ 9$ billion nine years later. On Second Marché created in 1983 in Paris, the number of listed companies rose from 18 in the first year to 292 in 1989 with the total market capitalization amounting to nearly FF190 billion (Ferrary, Groslambert 2004, p. 13). The initial development of these markets was influenced by favorable economic conditions and low interest rates encouraging 
investments on the stock market. The high valuation of share capital accounted for a large incentive for companies to raise funds from the stock market (Buckland, Davis 1989, p. 53-63).

After the collapse of global stock markets in October 1987, junior markets faced the problem of rapidly deteriorating liquidity and lack of IPOs. The USM's annual turnover in 1992 amounted to $£ 1,273$ million, which accounted for only $20 \%$ of the turnover in 1987. The average daily number of transactions fell during this time from 3,818 to 564 . In 1992, there were only seven IPOs. It was then decided for the market to be closed, yet the opposition of listed companies and some investors postponed the closing until 1996 (Rasch 1994, p. 5-8). The French Second Marché recorded only four IPOs in 1992. The annual turnover amounted to FF18.9 billion, a decline of over $70 \%$ compared to 1987 , when the turnover reached FF64.4 billion. The Belgian Second Marché, operating since 1984, listed only seven companies at the end of 1992.

Almost all markets for SMEs created in the 1970s and 1980s were closed after a few years of operation. The causes of their failures are not limited to the stock market meltdown starting in 1987, as the wrong assumptions made by the organizers were of great importance in this regard. As mentioned above, the stock markets established junior markets not to support SMEs in access to capital, but to ensure a steady flow of new issuers to the main trading floor. In addition, they thought at the time that the shares of small entities are too risky for investors and any irregularities in the operation of companies admitted to listing worsen the image of the entire stock market. Therefore, the conditions for admission to some of the junior markets, although less strict than on the main floor, were still a barrier for many companies. For example, in 1980 the main market of the London Stock Exchange was available for companies with a minimum capitalization of $£ 500$ thousand and bound to sell a minimum of $25 \%$ of the shares. It was also required to submit a prospectus containing financial statements for a period of at least 5 financial years. As for the newly created Unlisted Securities Market, there were no requirements in terms of capitalization and the minimum issuance was reduced to $10 \%$. However, a company still had to prepare a prospectus covering three financial years (Schmidt 1984, p. 49-60). In 1990, the criteria for admission to the main market were lowered, which resulted in many companies willing to wait until they meet the requirements to be listed on the main trading floor. In addition, the attitude towards the markets intended for SMEs as a sort of "incubator" for companies whose goal was to move to the main market resulted in a conviction among investors that junior markets retained only companies in weak financial condition and with no prospects for development.

The next stage in the history of creating special trading platforms for SMEs launched in 1995 with an attempt to start such a market by the LSE - Alternative Investment Market (AIM) commenced operation in June. By the end of the 1990s subsequent stock markets had renewed their attempts to organize such 
platforms: in 1996 the Parisian trading floor gained Nouveau Marché, a year later Euro.NM was established in Belgium and Amsterdam, and Neuer Markt in Frankfurt; in 1998, Nya Marknaden on the Stockholm Stock Exchange, in 1999, SWX New Market in Switzerland and NM-List in Finland (see: table 1). The circumstances and reasons for the creation of these platforms, however, were significantly different from those of their predecessors from the 1970s and 1980s. The conditions for the functioning of European capital markets had changed. Globalization, deregulation, and automation of markets, as well as the emergence of new financial instruments, intensified the competition between exchanges. The creation of new trading platforms was therefore the result of efforts to maintain or strengthen the competitive position of the exchanges (especially in the context of the intensive development of the OTC markets). To deliver their objectives, the stock exchanges had to ensure that the new markets for SMEs were not seen as inferior, secondary to the main trading platforms. For this purpose, they were modelled on the US NASDAQ, whose successful operation was based on solutions meeting the expectations and the needs of issuers and investors (Posner 2004, p. 23). Meanwhile, the stock markets emphasized the independence and autonomy of the junior markets against the main platforms and their purpose to support SMEs in obtaining financing, instead of supplying the main market with new issuers.

Assessing the effects of that attempt to create trading platforms for small and medium-sized enterprises (based on the number of IPOs and the value of collected and invested capital), the first years of their operation may be considered a success. In 1996-2001, a total of more than 900 companies raised in these markets about $€ 32$ billion. This result, although positive, is still far from the success of the US NASDAQ, which at that time was joined by over three times more companies acquiring twice as much funds from the public issue (Susi 2002, p. 4). The most dynamic of the European markets, the AIM, in 1995-2000 listed 829 companies acquiring a total of $£ 6,169$ million (of which 277 issuers and $£ 3,073$ million in 2000 alone). The year 2000 was also a record for the AIM in terms of the number of transactions (over 2 million) and their total value (over $£ 13,605$ million) (London Stock Exchange 2000). In 2001, equity markets collapsed as a result of the burst of the "Internet bubble" that had been forming since 1995. Stock exchanges were significantly affected by the flight of investors convinced of the significant revaluation of companies operating in the IT sector. Markets for SMEs once again faced the problems of liquidity, declining numbers of companies, capitalization, and issuance values. Again, decisions were made to close some of the junior markets. Another wave of declines affected the stock exchanges as a result of the global economic crisis that started in 2007 in the United States.

A drop in investor confidence and the transfer of savings from the stock markets to alternative investments always affects the markets especially designed for SMEs, which due to the special profile of issuers are perceived as riskier than the major 
markets. Therefore, the cyclical nature of the economy is one of the dangers for small trading floors. Another danger lies in the fragmentation of the capital market in Europe. While the US capital market is dominated by three stock exchanges (NYSE, NASDAQ and the NYSE MKT LLC ${ }^{3}$ ), in Europe, with several dozen exchanges and despite the integration processes within the European Union also present in the capital markets, there are still significant differences on the regulatory or organizational issues that restrict the flow of capital, increase transaction costs, affect the liquidity of individual markets, and ultimately determine their development.

\section{The pan-European market for SMEs}

In the history of the creation of markets designed for SME, a large role is played by the European Commission. According to E. Posner, the main catalyst for change in perceiving the need to create such markets by stock exchanges were the actions taken by the EC, rather than the increasing competition caused by the processes of globalization and the structural and organizational changes in the financial markets (more: Posner 2004; Posner 2009). The EC initiatives went far beyond the regulatory area of financial markets - the Commission is involved in the creation of EASDAQ, a pan-European market for SMEs. According to the EC officials, the then multinational financial system was the main reason for the lack of international competition and structural unemployment. The solution was to be a pan-European securities market, intended specifically for small and medium-sized enterprises, with the potential to promote entrepreneurship, growth, innovation and development of the European venture capital market. Achieving this goal, however, was not easy and took almost two decades. The conceptual work on this issue began in the 1970s. The milestone was the European Commission supporting the European venture capital markets in the appointment of the European Venture Capital Association (EVCA) in $1986^{4}$. The cooperation between the Commission and EVCA resulted in establishing the EASDAQ ten years later (Posner 2004, p. 24). The name was not accidental, as the EASDAQ in organizational, technological and regulatory matters was a copy of the NASDAQ. Adopting the NASDAQ solutions resulted not only from the EC conviction of successful support for SMEs. According to the data presented by the Commission in 1995, companies listed on the NASDAQ created $16 \%$ of new

3 Formerly known as AMEX - American Stock Exchange - taken over by NYSE Euronext in 2008, under the present name since May 2012.

4 EVCA: European Venture Capital Association. Present name: European Private Equity \& Venture Capital Association. 
jobs in 1990-1994. This effect was also crucial for the European Commission, due to high unemployment rates in Europe at the time (Liebman, Goodman, Hallake 1998). The Commission committed to the creation of a pan-European market also in the form of financial support. Funds for this purpose came from two programs: the Strategic Programme for Innovation and Technology Transfer 1989-1993 (SPRINT) and the multiannual program for small and medium enterprises 19931996 (Posner 2004, p. 31).

The EASDAQ, a regulated market within the meaning of the Directive on investment services (ISD) (Council Directive 93/22/EEC), was subject to Belgian legislation. Belgium was chosen as one of the first countries to implement the ISD. Moreover, the Belgian committee supervising the financial market accepted prospectuses in English, French, Dutch and German. The idea was also to avoid engaging in often a political game between the three major financial centers in Europe, i.e. London, Paris and Frankfurt, and Brussels was seen as neutral ground (Yassukovich 1997, p. 399). The EASDAQ shareholders were more than 90 institutional investors: investment companies, venture capital, banks, and brokerage houses.

Despite the efforts of the founders and the support of the European Commission, the EASDAQ failed to repeat the success of the American original. The pace of development differed from the assumptions and expectations of the organizers. It was assumed that in the first year the EASDAQ would list around 100 companies, joined by 500 issuers in each subsequent year. In fact, in December 2001, only 48 companies were listed. In 2001, the EASDAQ was taken over by the NASDAQ and changed its name to NASDAQ Europe, but ultimately did not survive the turmoil in the financial markets after the bursting of the Internet bubble and was closed (Ferrary, Groslambert 2004, p. 14-15). Although the attempt to create a pan-European market for innovative SMEs ended in failure, the action taken in this regard by the EC had significant consequences for the financial system, especially for stock exchanges afraid of losing their position in the domestic capital markets due to the outflow of investors, issuers and other market participants to the EASDAQ. In addition, there was uncertainty as to whether other exchanges would support the EASDAQ, or create their own markets for SMEs in response to a new competitor. In this way, the EC contributed to the development of competition between stock markets and changed their approach to the creation and functioning of special platforms for small and medium-sized enterprises.

\section{Bibliography}

Arcot A., Black J., Owen G. (2007), From local to global, The rise of AIM as a stock market for growing companies, The London School of Economics and Political Science, London.

Buckland R., Davis E.W. (1989), The Unlisted Securities Market, Oxford.

Council Directive 93/22/EEC of 10 may 1993 on investment services in the securities field (OJ EC L 141 of 11.06.1993, L 168 of 18.07.1995, L 290 of 17.11.2000 and L 35 of 11.02.2003). 
European Commission (2015), Annual Report on European SMEs 2014/2015 SMEs start hiring again, Belgium.

Ferrary M., Groslambert B. (2004), European Stock Market Financing for High-Growth Companies, Research Paper, European Private Equity and Venture Capital Association.

Jóźwiak-Mijal M. (2005), Luka Macmillana a znaczenie średnich przedsiębiorstw dla gospodarki, Studia i Materiały, Nr 1/2005, Wydział Zarządzania Uniwersytetu Warszawskiego, Warszawa.

Liebman H.M., Goodman S.M., Hallake M. (1998), Easdaq: the Pan-European Stock Market for Growth Companies, http://www.morganlewis.com/pubs/39A39A38-E17C-4A28-A8207BEE2D07067A_Publication.pdf (access: 15.04.2016).

London Stock Exchange (2000), AIM Market Statistics, December 2000, http://www.londonstockex change.com/statistics/historic/aim/aim-statistics-archive-2000/dec-2000.pdf (access: 15.04.2016).

Posner E. (2004), Copying the Nasdaq Stock Market in Europe: Supranational Politics and the Convergence-Divergence Debate, Working Paper PEIF-16.

Posner E. (2009), The Origins of Europe's New Stock Markets, Harvard University Press, Cambridge, Massachusetts, London.

Rasch S. (1994), Special Stock Market Segments for Small Company Shares in Europe. What Went Wrong?, Centre for European Economic Research (ZEW), Discussion Paper No. 94-13.

Schmidt H. (1984), Special stock market segments for small company shares: Capital raising mechanism and exit route for investors in new technology-based firms, Commission of the European Communities, Luxembourg.

Susi N. (2002), Venture Capital, Stock Exchanges for High-Growth Firms and Business Creation: a Study of IPOs on the Neuer Markt and the Nuovo Mercato, Quaderni di Finanza, No. 52.

World Federation of Exchanges (2016), Monthly Report 03/2016, http://www.world-exchanges.org/ home/index.php/statistics/monthly-reports (access: 30.04.2016).

Yassukovich S. (1997), EASDAQ: Europe's Stock Market for Growth Companies, Fordham International Law Journal, Vol. 21.

\section{GENESIS AND PREREQUISITES FOR CREATING STOCK MARKETS FOR SMALL AND MEDIUM-SIZED ENTERPRISES}

\section{Summary}

The appearance of trading platforms designed for instruments issued by SMEs on the European stock markets benefited not only the companies that gained a new source of funding, but also contributed to the rapid development of venture capital. A well-functioning market designed for SMEs benefits the whole economy in the form of encouraging entrepreneurship, provision of funds for the creation of new jobs and the development and implementation of innovative technologies. The best example confirming these positive effects is the US NASDAQ. In Europe, the barrier to the development of such platforms resulted from fragmentation of the capital market and the stock exchanges reluctant to create special trading floors for SMEs. The solution could have been a pan-European market focusing on both companies with high growth potential, representing innovative industries seeking capital for development, as well as the capital of equity investors spread over the European markets. The first initiative in this regard was taken by the European Commission and although the attempt failed ultimately, it had lasting effects in the form of institutional and organizational changes in the financial markets.

Keywords: stock exchanges, second-tier markets, alternative trading systems 


\section{GENEZA ORAZ PRZESŁANKI TWORZENIA GIEŁDOWYCH RYNKÓW AKCJI DLA MAŁYCH I ŚREDNICH PRZEDSIĘBIORSTW}

\section{Streszczenie}

Pojawienie się na europejskich giełdach platform obrotu przeznaczonych dla instrumentów emitowanych przez MSP przyniosło korzyści nie tylko spółkom, które zyskały nowe źródło finansowania, lecz wpłynęły także na intensywny rozwój działalności venture capital. Sprawnie funkcjonujący rynek przeznaczony dla MSP przynosi korzyści całej gospodarce w postaci pobudzania przedsiębiorczości, dostarczania środków na tworzenie nowych miejsc pracy oraz na rozwój i wdrażanie innowacyjnych technologii. Najlepszym przykładem potwierdzającym te pozytywne efekty jest amerykański Nasdaq. W Europie barierą rozwoju takich platform była zbyt duża fragmentacja rynku kapitałowego oraz niechęć giełd do tworzenia specjalnych parkietów dla MSP. Rozwiązaniem mógł być paneuropejski rynek skupiający zarówno spółki o wysokim potencjale wzrostu, reprezentujące innowacyjne branże, poszukujące kapitału na rozwój, jak i rozproszony po rynkach europejskich kapitał inwestorów. Pierwszą inicjatywę w tym zakresie podjęła Komisja Europejska i chociaż próba ostatecznie zakończyła się niepowodzeniem, to jednak pozostawiła trwałe efekty w postaci zmian instytucjonalnych i organizacyjnych na rynkach finansowych.

Słowa kluczowe: giełdy papierów wartościowych, rynki alternatywne, alternatywne systemy obrotu 